the age of 65 , though some kidneys from older donors have been used successfully.

Another important factor is the premortem perfusion of the kidney and the period of ischaemia after death before the kidney is removed. A kidney removed rapidly from the victim of a sudden fatal accident is likely to function much better than a kidney removed from a patient who has succumbed after a prolonged period of hypotension and shock. In these circumstances not only may the kidney have suffered tubular necrosis before it is removed, but there is a danger that the blood may be contaminated with organisms, which may be transferred with the kidney to the recipient and result in serious infection. A kidney left in a corpse for more than one hour at body temperature is also likely to suffer from severe tubular damage. This delay, often inevitable owing to the legal requirements of seeking permission for organ removal, has resulted in approximately $17 \%$ of kidneys transplanted in the United Kingdom never functioning at all. ${ }^{3}$

The Department of Health has recently issued an advisory document $^{4}$ aimed at improving the supply of kidneys for transplantation. This welcome move may help close the gap between the numbers of patients desperately needing kidney transplantation-about 2000 a year-and those actually receiving a kidney-approximately 500 a year. With better cooperation from the public and medical profession more than enough kidneys could easily be provided.

\footnotetext{
1 Tomlinson, S. A., et al., British Medical fournal, 1974, 4, 553.

2 British Medical fournal, 1975, 2, 710.

${ }^{3}$ British Transplantation Society, British Medical fournal, 1975, 1, 251.

${ }^{4}$ D.H.S.S., HSC (IS) 156, 1975.
}

\section{Prevention of Contact Dermatitis}

Contact dermatitis (eczema) is the most important form of dermatitis, requiring investigation and treatment by the family doctor, industrial medical officer, and the dermatologist. Endogenous forms such as seborrhoeic, nummular, and atopic eczema may in addition be modified by external factors, and the young atopic person in particular requires guidance on what are for him or her unsuitable occupations.

There is still no clear evidence that an atopic person is any more likely to develop contact dermatitis of the allergic type than are sufferers from other forms of endogenous eczema. ${ }^{1}$ Contact dermatitis usually results from physico-chemical damage to the skin and not from any recognizable immunological pathway. Most dermatologists would agree that an atopic person is predisposed to develop dermatitis or suffer aggravation of an already existing inflammatory reaction of the skin if he is exposed to friction, degreasing, cold, wet, and other forms of physical injury. Thus young people with atopic dermatitis require medical advice on careers early on, ${ }^{2}$ and every effort should be made to discourage them from taking up work that would entail exposure to physico-chemical injury, such as, for example, hairdressing, nursing, cooking, and certain wellrecognized parts of industry where dermatitis of the hands and arms is particularly likely to occur. The International Contact Dermatitis Research Group found that of 4000 people with contact dermatitis $68 \%$ had the hands affected, and that was the only site of the disease in about $50 \%{ }^{\circ}{ }^{1}$

This International Group, whose newsletter has recently become the journal Contact Dermatitis (No. 1 appeared in
January), has during the last few years continued to draw the attention of the medical profession, industry, and governments to the importance of contact dermatitis, the procedures which should be taken to aid diagnosis, and measures the individual and his employer can take to reduce the chances of dermatitis developing. It is doubtful if industry (either trade or profession) is in a position to select entrants on the basis of any clearly defined policy and the tendency is still to weed out the dermatitis sufferers as they occur. There are no satisfactory tests which will make this prior assessment possible. Skin tests for allergic sensitivity have no place and may even be harmful by inducing allergic sensitivity on occasions. What then to do? Perhaps we should concentrate our efforts more on the occupational hazards and their prevention. One undoubted advantage of the new National Health Service structure is the acceptance that a patient's welfare is the responsibility of the whole service. This should in time lead to quicker access from industry to the medical facilities available.

${ }^{1}$ Cronin, E., et al., Dermato-venereologica, 1970, 50, 183.

\section{Genetics of Duodenal Ulcer}

Gastric and duodenal ulcer often affect more than one member of a family. That could be due to chance coincidence, a similar response to the same environment, or a shared genetic predisposition. Family studies have shown that if several members of a family develop ulcers the ulcers tend to be of the same type, and liability to ulcer was roughly equal in members of different generations. This is modest evidence for the existence of genetic predisposition. ${ }^{12}$

Ian Aird and his colleagues found that peptic ulcer was especially frequent in people of group $\mathrm{O}^{3}$ This finding has been confirmed many times, ${ }^{4}$ and it has been expanded by the discovery that people who cannot produce their $\operatorname{ABO}(H)$ blood group substances in water-soluble form in their secretions are also specially liable to ulcer $^{5}$ (this characteristic is inherited independently of $\mathrm{ABO}$ blood groups). It has also been found that complications of ulcer, especially bleeding, are particularly apt to occur in people of group O. ${ }^{67}$ These variations are only slight, and they have been interesting more for the light they might throw on the causation of ulcer than for their clinical significance.

Lam and Sircus ${ }^{8}$ have recently suggested that when, in patients with duodenal ulcer, the $\mathrm{ABO}$ blood groups and the secretory output of gastric acid in response to pentagastrin are considered together a consistent pattern emerges. People of group $\mathrm{O}$ tended to have a relatively low output of acid and to be prone to perforation, bleeding, and stenosis; those of groups $\mathrm{A}, \mathrm{B}$, and $\mathrm{AB}$ to be acid hypersecretors, prone to develop the disease earlier, and to have the strongest family prevalence. They further consider that separation into these two groups may help in determining the proper surgical procedure for each type of ulcer, for they suggest that the group $\mathrm{A} / \mathrm{B} / \mathrm{AB}$ hypersecretory ulcer develops on a background of parietal cell hyperplasia, while the group $\mathrm{O}$ normosecretory ulcer occurs in a patient with an overactive gastric antrum.

If the authors are correct, a number of observations need reconciling with their data. Firstly, the interrelationship of secretor status with their proposed system needs delineation. The most obvious hypothesis would be that $\mathrm{ABO}(\mathrm{H})$ nonsecretion is associated with a normal acid output, since there 
would then be a direct correspondence between group $\mathrm{O}$ and non-secretion, while $\mathrm{ABO}(\mathrm{H})$ secretors, with their reduced liability to ulcer, would tend to have a high acid output, the counterparts of groups $\mathrm{A}, \mathrm{B}$, and $\mathrm{AB}$. However, previous results have suggested that acid or pepsinogen output and secretor status are not correlated. ${ }^{9-13}$ Further, there is much earlier evidence in which attempts were made to correlate patients' blood groups with acid output or serum pepsinogen levels. These have fallen into two main groups: either no correlation was found, ${ }^{9-1215}$ or the output of acid or pepsin was marginally increased in those of group $0 .{ }^{131416}$ The divergence from the latest studies is difficult to understand. The need now is for analysis of more sets of data before the clinical significance of the new data can be properly decided.

${ }^{1}$ Doll, R., and Buch, J., Annals of Eugenics, 1950/1951, 15, 135.

2 Doll, R., and Kellock, T. D., Annals of Eugenics, 1951/1952, 16, 231.

3 Aird, I., et al., British Medical fournal, 1954, 2, 315.

${ }^{4}$ McConnell, R. B., The Genetics of Gastrointestinal Disorders. London, Oxford University Press, 1966.

5 Clarke, C. A., et al., British Medical fournal, 1956, 2, 725.

${ }^{6}$ Langman, M. J. S., and Doll, R., Gut, 1965, 6, 270.

${ }^{7}$ Horwich, L., et al., Gut, 1966, 7, 680.

${ }^{8}$ Lam, S. K., and Sircus, W., Quarterly fournal of Medicine, 1975, 44, 369.

9 Ventzke, L. E., and Grossman, M. I., Gastroenterology, 1962, 42, 292.

10 Denborough, M. A., Australasian Annals of Medicine, 1966, 15, 314.

11 Fodor, E. O., et al., American fournal of Digestive Diseases, 1968, 13, 260.

12 Niederman, J. C., Gilbert, E. C., and Spiro, H. M., Annals of Internal Medicine, 1962, 56, 564.

${ }^{13}$ Hanley, W. B., British Medical fournal, 1964, 1, 936.

14 Veselý, K. T., Kubičková, Z., and Dvoŕáková, M., Gut, 1968, 9, 57.

15 Novis, B. H., et al., Gut, 1973, 14, 107.

${ }^{16}$ Koster, K. H., Sindrup, E., and Seele, V., Lancet, 1955, 2, 52.

\section{Liver Injury}

High-speed road traffic accidents, civil strife, common assault, and armed conflict ensure that the incidence of liver injury remains high. Haemorrhage and biliary leakage, together with difficulties in diagnosis, in assessing the extent of damage, in operative treatment, and in the recovery period present a formidable surgical challenge.

Though variations in the availability of rapid transport and good resuscitative facilities must make comparison of results hazardous, ${ }^{1}$ a remarkable improvement is discernible since the 1960s. While multiple injuries account for many deaths, few patients should now die of isolated liver injury. After the second world war reports by several authors ${ }^{2-4}$ documented considerable improvement in survival. Among the reasons given were the change from the packing of liver wounds to suture ligation of bleeding points, the employment of antibiotics, and appropriate drainage. These methods, together with debridement of devitalized liver tissue and occasional hepatic lobectomy for extensive shattering wounds, have proved effective in the treatment of some injuries. Indeed, in a recent series of 270 patients treated by Walt ${ }^{1}$ only 5 with stab wounds died; the complication rate, largely the result of wound infection and pulmonary atelectasis, was $12 \%$. The mortality for gunshot wounds is higher, at about $12 \%$, though that in American casualties in Vietnam, mainly from high-velocity missile wounds, was somewhat less. ${ }^{5} 6$

The mortality from blunt liver injury has shown the most dramatic decrease-from $60 \%{ }^{78}$ to $30 \%$ or less. ${ }^{19-11}$ Even for the most severe injuries, requiring hepatic resection, mortality is now less than $40 \% 112$ and most deaths occur in association with severe damage to the head or chest. A useful distinction between the more minor forms of injury and major disruptive wounds has been made by Blumgart and
Vajrabukka ${ }^{10}$ The former can usually be managed by suture ligation and drainage. Indeed, if haemorrhage has ceased, simple drainage will suffice. But the dangers of gauze packing of large destructive wounds of the liver have been well demonstrated, and hepatic resection, either in the form of resectional debridement or hepatic lobectomy, has been accepted in the management of very extensive blunt injuries. ${ }^{1} 1012-14$ Some authors have recently shown that hepatic arterial ligation, combined with debridement, can be of value in some cases of major liver damage ${ }^{1516}$ However, dissection of the relevant branches of the hepatic artery can be difficult, especially where there is much bruising about the porta hepatis. It would seem that arterial ligation is a development which has a place in some severe cases, but it should always be accompanied by debridement of obviously dead tissue. Damage to major blood vessels such as the portal vein, hepatic artery, and particularly the vena cava provides an only partially solved problem. ${ }^{17-21}$ The late appearance of an intrahepatic haematoma, presenting as haemobilia or as a liver mass, is a dangerous condition, and it should remain as a diagnostic possibility in the clinician's mind.

Mortality and morbidity are related to delay in treatment. While prompt diagnosis is therefore important, it has been pointed out that, particularly in blunt injury, up to $30 \%$ of patients may present without gross signs of intra-abdominal damage. Consequently the possibility of liver damage has to be borne in mind. Indeed a recent survey in the United Kingdom showed that up to $51 \%$ of patients with blunt abdominal injury had damage to the liver. ${ }^{22}$ Special investigations have a limited place in diagnosis. Liver scan and selective coeliac axis angiography are not generally available and may give false-negative results. Similarly, though abdominal paracentesis and peritoneal lavage have their advocates, intra-abdominal injury may exist despite a negative result. Laparotomy on suspicion is justifiable; there is no place for conservative management in suspected liver injury. Nevertheless, when special investigations are available in major centres, they can be valuable in detecting damage before the need for laparotomy becomes evident on physical examination, and they are certainly of value in detecting the latepresenting intrahepatic haematoma.

1 Walt, A. J., Annals of the Royal College of Surgeons, 1969, 45, 319

2 Sparkman, R. S., and Fogelman, M. J., Annals of Surgery, 1954, 139, 690.

${ }^{3}$ Crosthwait, R. W., et al., Surgery, Gynecology and Obstetrics, 1962, 114, 650.

${ }^{4}$ McClelland, R., and Shires, T., Annals of Surgery, 1965, 161, 248.

5 Pilcher, D. B., Annals of Surgery, 1969, 170, 793.

6 Carroll, C. P., Cass, K. A., and Whelan, T. J., Annals of Surgery, 1973, $177,385$.

7 Mikesky, W. E., Howard, J. M., and DeBakey, M. E., International Abstracts of Surgery, 1956, 103, 323.

${ }^{8}$ Foster, J. H., et al., Annals of Surgery, 1968, 167, 651.

9 Little, J. M., and Williams, C. W., British fournal of Surgery, 1969, 56, 603.

${ }^{10}$ Blumgart, L. H., and Vajrabukka, T., British Medical fournal, 1972, 1, 158.

11 Donovan, A. J., Michaelian, M. J., and Yellin, A. E., Surgery, 1973, 73, 833.

12 Vajrabukka, T., et al., British fournal of Surgery, 1975, 62, 189.

13 Balasegaram, M., Annals of the Royal College of Surgeons of England, 1970, 47, 139.

${ }^{14}$ Little, J. M., Management of Liver Injuries. Edinburgh, Livingstone, 1971.

15 Mays, E. T., Fournal of Trauma, 1972, 12, 397.

16 Mays, E. T., New England Fournal of Medicine, 1973, 288, 402.

17 Schrock, T., Blaisdell, F., and Mathewson, C., Archives of Surgery, 1968, 96, 698.

18 Bricker, D. L., et al., Fournal of Trauma, 1971, 11, 725.

19 Hanna, W. A., and Wisheart, J. D., Fournal of the Royal College of Surgeons of Edinburgh, 1969, 14, 328.

20 Inberg, M. V., and Ahonen, J., Acta Chirurgica Scandinavica, 1971, 137, 93. 21 Morton, J. R., Roys, G. D., and Bricker, D. L., Surgery, Gynecology and Obstetrics, 1972, 134, 298.

22 Bolton, P. M., et al., British fournal of Surgery, 1973, 60, 657. 